\title{
NAGYVÁROSI KORMÁNYZÁS: A VÁROS ÉS KÖRNYÉKE EGYÜTTMÜKÖDÉSE KÜLFÖLDI PÉLDÁK ÉS A HAZAI RELEVANCIA
}

\author{
(City-region Governance: the Cooperation between the City and \\ the Metropolitan Area. \\ European Examples and the Relevance for Hungary)
}

\author{
TOSICS IVÁN
}

Kulcsszavak:

városkörnyéki közigazgatás többszintü kormányzási struktúrák versenyképesség és fenntarthatóság európai nagyvárosi várostérségek összehasonlitása Budapest és térsége

Az európai fejlődés versenyképesebbé és fenntarthatóbbá tétele érdekében egyaránt alapvetően fontos a városok és a körülöttük lévō területek közötti valós együttmüködés. A 21. századi új városrégiós együttmüködési idöszak különbözik a korábbiaktól, fixen körülhatárolt új közigazgatási szintek helyett ma inkább rugalmasabb együttmüködési formák képzelhetôk el, nagyobb hangsúllyal a kormányzásra (governance) és a hálózatszerü struktúrákra. A „városrégiók" elött kettős feladat áll: a szükebb, funkcionális városi terület belsỏ konfliktusainak megoldása, illetve a bỏvebb városi terület gazdasági együttmủködési lehetỏségeinek kiaknázása. Elöbbihez szükség lehet felülröl kialakitott szabályozó rendszerekre, mig utóbbiak rugalmas, alulról épitkezö partnerség keretében müködhetnek a legjobban. A budapesti térségben ma szinte egyáltalán nincs térségi kooperáció, sem a szủkebb funkcionális térben, sem a tágabb gazdasági befolyási övezetben. Az együttmüködés és az ezen alapuló, közös akaratot tükröző szabályozások és fejlesztési elképzelések hiányában a budapesti térség sem belső problémáit nem tudja megoldani, sem pedig kedvezó európai fejlödési potenciáljait nem tudja kihasználni.

\section{Bevezetés}

Nincs kétség arról, hogy nagyváros és környéke sok szálon összefügg egymással. Ez egy kétoldalú kapcsolat: a környéken élök legtöbbször a városban dolgoznak, odajáratják gyerekeiket iskolába, ott vásárolnak, mennek moziba, múzeumba, színházba. A városlakók pedig sokszor a környéken kirándulnak, ott vesznek hétvégi házat, telket, vagy éppen oda vágynak kiköltözni, amikor a gyerekek megszületése után megnő a kertes ház irảnti igényük. A beruházók, munkahely-teremtők, irodaházat vagy éppen bevásárlóközpontot építők is legtöbbször egységben nézik a funkcionálisan összetartozó térséget, amikor helyszínt keresnek újabb terveik megvalósításához.

A nagyváros és környéke között létező szoros kapcsolat sok lehetöséget és egyúttal problémát teremt, amelyek miatt indokolt lenne e térségekben valamilyen formalizált kormányzási struktúra kialakítása. A lakóhely-munkahely kapcsolat idóben koncentrált közlekedési igényeket szül, melyek zsúfoltsághoz, a városba bevezetỏ utak kaotikus állapotához vezethetnek. Problémát jelent a városi szennyvíz, szemét 
Tosics Iván : Nagyvárosi kormányzás : A város és környéke együttmüködése. Külföldi példák és a hazai relevancia.

Tér és Társadalom 22. évf. 2008/1.

elhelyezése. Ugyahakkor nagy elönyt jelent egy város számára, ha tágabb környékével jól tud egyưuttmúködni, mert ilyenkor sokszínủbb kínálatot nyújtó, nagyobb egységként tud megjelenni a befektetési helyszínek globalizált versenyében.

A szoros kapcsolat ellenére nagyváros és környéke a legritkább esetben tartozik össze adminisztratív-közigazgatási értelemben. Magyarországon a nagyfokú települési önállóság élesen elválasztja egymástól a várost és a környékén lévő településeket. Ezen a kistérségi, megyei vagy regionális szerveződés sem sokat változtat, mivel ezek egyrészt gyengébbek a települési szintnél (a kistérség és a régió csak delegált szint, míg a megye ugyan választott, de a bevételeket és a funkciókat tekintve nagyon szúk mozgásterú), másrészt pedig általában térben nem képezik le a funkcionális nagyvárosi térséget, annál kisebbek vagy nagyobbak.

A város és környéke együttmúködése Magyarországon soha nem kapott kiemelt figyelmet. Nem kedvez ennek a témakörnek az önkormányzati rendszer decentralizáltsága és a közszféra különböző szereplői közötti kooperációs kapcsolatok gyengesége sem. Viták csak a megyei és regionális rendszerről folytak az utóbbi időben, a városkörnyéki igazgatáshoz talán leginkább közel álló kistérségek ügye ezekhez képest hátrébb rendelődött. İgy az Európa-szerte újra népszerủ városkörnyéki témakör inkább csak külföldi példák alapján tanulmányozható.

Jelen írás célja, hogy néhány európai város példájából kiindulva áttekintse a nagyvárosi térség müködésének és szerveződésének problémảit és lehetőségeit. A kiindulópontot a METROGOV elnevezésủ nemzetközi együttműködési projekt adja, amelynek keretében nyolc város képviselői másfél évig dolgoztak együtt e témakörben. A projekt vezetője Birmingham városa volt, tagjai között ott szerepelt $\mathrm{Bu}$ dapest, jelen tanulmány szerzője pedig a projekt szakértőjeként tevékenykedett. Ez az írás nagymértékben támaszkodik a METROGOV projekt zárótanulmányára (Homan-Howl-Tosics 2007).

A tanulmány szerkezete a következö: A problémafelvetést a különböző elméleti megközelítések, majd a METROGOV városok példáinak áttekintése követi. A kormányzati, pénzügyi, partnerségi szempontok tárgyalása, majd pedig az összehasonlítás eredményeinek összefoglalása után néhány felvetés szerepel arra vonatkozóan, hogyan lehetne a megismerteket Budapest esetében hasznosítani.

\section{A nagyvárosi térségek: kettös kihívás és az eddigi válaszok}

Az európai városoknak manapság olyan külső kihívásokkal és belső változásokkal kell szembenézniük, amelyekre a város és környéke csak együttmüködésben tud optimális válaszokat adni.

- A globalizációnak, a nemzetközi kereskedelem növekvő szerepének és a nagy multinacionális gazdasági szereplök jelenlétének külsỏ kihívására a városoknak növekvő versenyképességgel kell válaszolniuk. Csak a környező térségekkel való együttmüködés biztosítja a gazdasági erőt és méretgazdaságosságot a városok számára, hogy a nemzetközi piacon versenyképesek tudjanak maradni. 
Tosics Iván : Nagyvárosi kormányzás : A város és környéke együttmüködése. Külföldi példák és a hazai relevancia.

Tér és Társadalom 22. évf. 2008/1.

- A belső kihívások sok városban a szuburbanizáció, illetve a tagolatlan városi terjeszkedés formájában jelentkeznek, megnövelve a társadalmi és környezeti ellentmondásokat a nagyvárost körülvevő térségben. A belső területi szerkezet megújitásához szintén együttmüködésre van szükség a környező térséggel.

Annak érdekében, hogy az adminisztratív struktúrák hatékonyabban megfeleljenek ezeknek a kihívásoknak, a nemzeti kormányok régóta igyekeznek reformokat végrehajtani az adminisztratív-közigazgatási rendszereken. Az 1960-as és 70-es években a központi kormányzatok nagyvárosi közigazgatási rendszerek létrehozásával próbálkoztak, az önkormányzatok összevonása vagy új kormányzati szint létrehozása által (OECD 2000, 6). Az 1980-as és 90-es években azonban abbamaradtak ezek az erófeszítések, sőt, a korábban kialakított struktúrák nagy része is megszünt, így került sor például a nagyvárosi tanácsok (metropolitan councils) megszüntetésére az Egyesült Királyságban ${ }^{1}$. A nagyvárosi szint elleni „támadások” részben felülről (politikai megfontolások), részben pedig alulról érkeztek (a lakosság bizalmatlansága). Utóbbi azt jelenti, hogy az új kezdeményezések általában népszerútlenek voltak a lakosság körében - ennek tudható be például a „várostartományok" (city-provinces) létrehozása ötletének bukása Hollandiában a helyi népszavazások során (Kreukels 2000, 474).

Az 1990-es évek végétől a nagyvárosi kormányzás gondolata ủjjáéledt. A kezdeményezés nemzetközi think-tank támogatóinak egyike, az OECD pozitív példákként említi Bologna, Toronto, Mexikóváros és London eseteit, mint a stratégiai tervezés és a struktúrák kialakításának szabályozási és végrehajtási hatáskörrel is járó kísérleteit $(O E C D$ 2000, 6). Az új kezdeményezések abban különböznek a korábbiaktól, hogy nagyobb hangsúlyt helyeznek a kormányzásra (governance), a hálózat-jellegú struktúrákra és a rugalmasságra.

A nagyvárosi kormányzás problémakörét el kell választani a regionalizációtól. A régiók kialakítása nagyon fontos, különösen a centralizált országokban. A régióknak a nemzetállamokkal szemben megnövekedett jelentőségét alátámasztva az Európai Unió a regionalizáció elvének egyik fő támogatója. Kohéziós politikáját néhány évtizeddel ezelött nemzetiről regionális szintüre alakította át, létrehozva a NUTS2 régiók rendszerét, mint a pénzügyi elosztás szintjét a Strukturális Alapok vonatkozásában. Ennek következtében az elmúlt tíz év során a régiók szerepe megnőtt. Ezeknek a régióknak a nagysága azonban általában jóval meghaladja a nagyvárosok körüli funkcionális városi térségét, tehát a NUTS2 régiók kialakítása általában nem oldja meg a nagyváros-környék szintủ kormányzás hiányának problémáját. Az újonnan kialakított és politikailag erős NUTS2 régiók adott esetben éppen ellenérdekeltek lehetnek a funkcionális nagyvárosi régiók kialakulásában, ezért gátolhatják a folyamatot, mivel a szúkös erőforrások megszerzéséért folytatott küzdelemben potenciális versenytársat láthatnak bennük. 
Tosics Iván : Nagyvárosi kormányzás : A város és környéke együttmüködése. Külföldi példák és a hazai relevancia.

Tér és Társadalom 22. évf. 2008/1.

\section{Városkörnyéki együttmüködés: különbözö elméleti megközelitések}

A városkörnyéki együttmúködés a többszintủ kormányzás témakörének szerves része. $\mathrm{Az}$ OECD értelmezése szerint a többszintü kormányzás a hatalom és a kapcsolatok különbözö dimenzióinak a kormányzati szinteken átívelő gyakorlása illetve kezelése. A kormányzásban fontos változásokat figyeltek meg, elsősorban a regionális és helyi kormányzati szintekre történő, fokozódó decentralizációt. Ugyanilyen fontos azonban, hogy a szintek között interakció zajlik és a partnerek képesek a közpolitikák befolyásolására (OECD 2000; Townsend 2005). A 'többszintü' kormányzás kifejezés evolúciója Európában arról szól, hogy a hatalmat és az erőforrásokat a legmegfelelóbb szintre eljuttatva lehetővé váljon a stratégiai prioritások lehető legsikeresebb realizálása. „A hatalomnak ez az újraelosztása történhet fölfelé, lefelé, illetve oldalirányban" (Hooghe-Marks 2001, 1), tehát nem kizárólag felülről lefelé irányuló kezdeményezés kell legyen, hanem kölcsönös és többirányú folyamat.

A kihívás minden nagyváros számára abban áll, hogy világos elképzelést alakítson ki arra vonatkozóan, hogy saját városkörnyéki, városrégió-szintư ${ }^{2}$ kormányzása hogyan illeszthető be legjobban a már meglévő, müködő rendszerbe. Ezen túlmenően a városrégióknak ki kell dolgozniuk koncepciójukat a többi kormányzati szinthez, illetve szakma-politikákhoz való viszonyulásukra, továbbá arra vonatkozóan, hogyan müködjenek együtt 'horizontálisan' a többi városrégióval. Alapos megfontolást igényel, hogy melyek azok a funkciók, amelyek 'le-delegálhatók' a városrégió szintjére, pl. európai finanszírozás vagy a nemzeti források/feladatok formájában, illetve melyek azok, amelyek 'feltölthetők' erre a szintre.

\section{A többszintü kormányzási rendszer müködésére vonatkozó nézetek}

A városi/nagyvárosi térségekkel kapcsolatos egyik legfontosabb kérdés az, hogy múködésük formális intézményeken alapuljon-e, vagy maradjon informális/önkéntes. A következőkben két alapvető megközelítés kerül bemutatásra, a 'formális, törvény szerint kialakítandó (statutory)' nagyvárosi kormányzási modell, melyet a METREX (az európai nagyvárosi régiók és térségeik hálózata) anyagai reprezentálnak, és az informálisabb, alulról-felfelé építkező 'kreatív kormányzás' elmélete Balducci-Kunzmann-Sartorio (2004) nyomán.

\section{METREX és a 'nagyvárosi kormányzás'}

A METREX hálózat által készített részletes elemzés (2005) azt mutatja, hogy a nagyvárosi térségek hatékony és integrált gazdasági, szociális, környezetvédelmi és területi tervezéséhez több feltétel szükséges:

- megfelelő kompetenciák: a nagyvárosi területi tervezés jóváhagyásának, megvalósításának és felügyeletének hatásköre,

- felkészültség: a megalapozott döntéshozatalhoz szükséges szakértelem és tudás, 
Tosics Iván : Nagyvárosi kormányzás : A város és környéke együttmüködése. Külföldi példák és a hazai relevancia.

Tér és Társadalom 22. évf. 2008/1.

- eljárások: a stratégia rendszeres nyomon követésének, felülvizsgálatának és megújitásának eszközei és feltételei.

A METREX hálózat három különböző, jelenleg Európa-szerte használt 'nagyvárosi' modellt azonositott ( NLGN 2006):

- Az átfogó (comprehensive) modell. Választott nagyvárosi kormányzat átfogó hatáskörrel a stratégiai tervezés és végrehajtás terén. Ehhez általában a meglévő helyi adminisztratív szerkezet újjászervezésére van szükség (példa: Hannover tartományi fóváros).

- A szükitett (core power) modell. Választott vagy delegált tagokból álló hatóság, mely a stratégiai tervezés területén belül csak meghatározott kérdésekben rendelkezik hatáskörrel (példa: Verband Region Stuttgart).

- Az ügynökségi/önkéntes (agency/voluntary) modell. Delegált tagokból álló nagyvárosi (a városra és környékére, a metropolitán területre egyaránt kiterjedö) ügynökségek vagy közös testületek stratégiai tervezési feladatkörrel és a végrehajtást illetően tanácsadói funkcióval (példa az Öresund Bizottság).

Ennek megfelelően a nagyvárosi kormányzás eszközei és intézményei is különböző formákat öltenek, a nagyvárosi kormányzattól és akár az egybeolvadástól (Montreal) az adóverseny csökkentését célzó adóalapú közteherviselésen és újraelosztáson át az egy- vagy többcélú nagyvárosi ügynökségekig.

A fenti modellekre vonatkozó kutatás azt mutatja, hogy minél tágabb területileg a városmag körüli városrégió, annál lazább együttműködés érhető csak el. A nagyvárosi funkcionális és közigazgatási térségek közti kapcsolat elemzéséből kiderül továbbá, hogy a legjobb forgatókönyv az, amikor ez a kettő egybeesik: ahol ugyanis a nagyvárosi terület több közigazgatási területre oszlik, ott nagyobb a valószínủsége a kooperációs problémáknak és az adóversenynek.

2005-re a METREX 32 európai várossal együttmúködve kifejlesztett egy eszközt, amely lehetôvé teszi annak tesztelését, mennyire erös a nagyvárosi kormányzat egy adott térségben. A METREX Practice Benchmark 29 indikátort tartalmaz, melyeket a következőképpen csoportosítottak:

- Kompetencia (8 mutató): milyen hatáskörrel rendelkezik a városrégió egy nagyvárosi stratégia jóváhagyását, megvalósítását és felügyeletét illetỏen?

- Felkészültség (13 mutató): milyen mértékben rendelkezik a városrégió a megalapozott területi tervezéshez és fejlesztési döntéshozatalhoz szükséges tudással, szakértelemmel?

- Eljárások (8 mutató): milyen mértékben vannak meg a városrégióban egy nagyvárosi stratégia nyomon követésének, felülvizsgálatának és megújitásának eszközei?

A METREX hálózat egy politikai nyilatkozatot is kiadott az európai nagyvárosokra vonatkozó cselekvési terv megalkotásának szükségességéröl (European Agenda for Metropolitan Europe). Ez azon a meggyöződésen alapul, hogy a városok versenyképessége és kohéziója a leghatékonyabban úgy javítható, hogy a nagyobb városok 
Tosics Iván : Nagyvárosi kormányzás : A város és környéke együttmüködése. Külföldi példák és a hazai relevancia.

Tér és Társadalom 22. évf. 2008/1.

8 Tosics Iván

TÉT XXII. évf. 2008

esetében a funkcionális városi térség (városrégió) szintjén kialakítják a stratégiai döntéshozatal hatékony eszközeit.

\section{A „,kreatív városrégió-kormányzás” koncepciója}

Ez a megközelítés jelentős mértékben különbözik a METREX-étől, mivel a kiindulópontja az, hogy a nagyvárosi térség felülről jövő, egységes definíciójára tett kísérletek általában csődöt mondanak, míg a rugalmasabb határokkal és elrendezéssel operálók (a hosszú távú kötelezettségvállalásra vonatkozó garanciák megléte mellett) jobban müködhetnek (Balducci et al 2004). Példaként Olaszország 1990-ben és Németország 1997-ben elfogadott városkörnyéki politikáit hozzák fel, amelyek véleményük szerint a gyakorlatban alig müködnek.

$\mathrm{Az}$ átláthatóságot és a partnerek bevonásának szükségességét alátámasztó német példák alapján Kunzmann (2004) megfigyelte, hogy a nagyvárosi térségek kreatív kormányzásának egyik legfontosabb aspektusa a regionális információs rendszerek felépítése, illetve az összes fontos szereplő bevonása az együttgondolkodás megvalósítása érdekében. Amennyiben ez sikerül, a városrégió-identitás és öntudat kialakulásának valószínüsége megnő, melynek pozitív hatása nemcsak befelé érvényesül, hanem kifelé, a befektetök és versenytársak felé is.

A kreativ kormányzás szakirodalmában a meglévő rendszerekkel kapcsolatos egyik kulcsproblémának a bürokratikus, esetenként túladminisztráló, az innovatív gondolkodás elfojtásával fenyegető tendenciák erősségét látják (Healy 2004; Kunzmann 2004). A sikeres kormányzási mechanizmusok ugyanakkor elösegítik a kreatív ötletek 'felfelé vándorlását' a hierarchián belül. A szerzők javasolják továbbá a kockázatkerülő felfogás megváltoztatását, „... a kísérletek ugyanúgy vallhatnak kudarcot, mint ahogy sikerre is vezethetnek" (Healy 2004, 90), valamint a reflexívebb megközelítést azokban a helyzetekben, amikor lehetőség nyílik új elképzelések és struktúrák értékelésére és alkalmazására.

A városok által alkalmazható, javasolt mechanizmusok közül néhány:

- Rugalmas, funkcionális határok megengedése.

- A már meglévő intézmények lokálpatriotizmusán való felülkerekedés.

- Az innovatív regionális szereplök hálózatának fejlesztése, a kormányzási mechanizmusok fejlesztésébe történó bevonása.

- A társadalmi és környezetvédelmi felelösségvállalás erősítése érdekében a „harmadik szektor” fokozottabb bevonása.

- Katalizátor-projektek tervezése (a közös projekt növeli az együttműködés lehetőségét).

- A rugalmas berendezkedés lendületének megtartása a szereplök találkozási lehetőségeinek biztosításával akkor is, ha nem születnek konkrét döntések.

- A folyamat átláthatóságának biztosítása, az innovatív ötletek irányában nyitott hozzáállás. 
Tér és Társadalom 22. évf. 2008/1.

A kreatív kormányzás szemlélete tehát támogatja a rugalmasságot, felhívja a figyelmet a sztenderdizált, mindenki számára egyforma (one size fits all) javaslatok veszélyeire, hangsúlyozva a helyi társadalmi, kulturális, történelmi és gazdasági kontextus szerepét.

\section{Formális és informális kormányzás}

Clark $(2005,14)$ listát készített a városrégió együttmüködési formáiról, a 'lazá'tól a 'szoros'-ig:

- Közös arculat és marketing kifelé (külső csoportok, beruházók felé),

- Együttmúködési megállapodások/koalíció,

- Közös tervezés/jövőkép/stratégiaépítés,

- Közös vállalkozások és katalizátor-projektek,

- Megosztott kapacitások és infrastruktúra,

- Kormányzási reformok

- Vezetői csoportok ${ }^{3}$

- Szolgáltató céltársaságok

- Egybeolvadás.

A fenti lista elemei informálisnak mondhatók, az utolsó sorban szereplö kormányzási reform kivételével, amely a formális címkét kaphatja. Egy városi térségben többféle forma is müködhet egyszerre, ugyanakkor a történelmi és kulturális tényezők vagy törvények kizárhatják a fent felsorolt lehetőségek némelyikét.

\section{A nagyvárosi térségek alapfeladatai}

A nagyvárosi térség szintjén sokféle feladatot kell megoldani. Az eltéró típusú feladatok a nagyvárosi térségekre vonatkozóan különböző kormányzati megközelítéseket és területi szemléletet igényelhetnek.

A feladatok között egyfelöl vannak pozitív (win-win) ügyek, mint pl. a versenyképesség és tömegközlekedés javítása, melyek esetében könnyebb a partnerek közötti együttmüködés, mivel siker esetén minden szereplő jỏl jár. Másfelől vannak olyan szabályozási feladatok, amelyek inkább a „zérus összegü játék” logikáját követik, mint például a hulladékkezelés. A 'pozitiv' ügyek föleg gazdasági, míg a 'szabályozási' kérdések nagyrészt társadalmi és környezetvédelmi jellegüek. Általában elmondható, hogy a pozitív gazdasági témák körül könnyebb együttmúködést kialakítani, mint a szabályozási jellegü feladatok körül.

\section{Városrégiók és versenyképesség}

Régóta folyik a vita a 'területi versenyképesség'-ről, a közgazdászok egy része ugyanis kétségbe vonja, hogy használható-e a gazdasági versenyképesség fogalma területi egységek esetében. Ennek ellenére egyre többen elismerik, hogy van értelme a 
„városok versenyképességéröl” beszélni, és hogy ezen a teljes funkcionális térséget kell érteni, nem csupán a szüken vett várost magát (Tosics 2005b, 79).

Nyilvánvaló, hogy a regionális változások motorjai a városok: ,[Európában] a legversenyképesebb régiókban találhatók a legversenyképesebb városok - nem találtunk példát olyan sikeres régióra, melynek szívében sikertelen városok lettek volna" (Parkinson 2004, 53). Annak ellenére, hogy a régiók fontos szerepe elismert, növekvő konszenzus mutatkozik abban, hogy a régiók túl nagy egységek ahhoz, hogy a versenyképesség kérdéseivel megbirkózzanak. Ugyanakkor az is világos, hogy a közigazgatási városok túl kis egységek, hiszen a fejlesztésekhez szükséges területek és egyéb feltételek sok esetben a városhatáron kívül találhatók. Leginkább a funkcionális városi térség adhatja tehát a gazdasági teljesítmény javításához szükséges megfelelö kritikus tömeget és szakértelmet.

A szabadság és rugalmasság mellett a versenyképességhez erös vezetésre van szükség, amely innovatív, átalakítás-párti, jövőképpel rendelkezö és más városrégiókkal is partneri kapcsolatban áll. A vezetésnek fontos szerepe lehet abban, hogy a különbözö, a versenyképesség javulása szempontjából kulcsfontosságú szereplök (a közszférán kívül pl. az egyetemek és a magánszektor) között kialakuljanak a kapcsolatok.

$\mathrm{Az} \mathrm{OECD}$ várospolitikai paradigmaváltást lát abban, hogy a passzív, reagáló magatartástól egyre gyakoribb az elmozdulás a pro-aktív szemlélet felé, melyet a versenyképesség javítása érdekében dinamikusabb irányelvek vezérelnek (Kim 2006). A városok kezdik megerösiteni klaszter-kapcsolataikat, mobilizálni innovatív kapacitásaikat és emberi erőforrásaikat; továbbá gazdasági eredményeiket javítandó befektetnek látnivalóik vonzerejének növelésébe és az életminőség javításába. Mindezek mellett növekvő figyelmet kell fordítani a társadalmi kirekesztés és a munkanélküliség kérdéseinek kezelésére is (Jones et al 2006).

\section{Városrégiók és környezetpolitikai szabályozási kérdések}

A versenyképesség javításán kívül a sikeres nagyvárosi térségeknek a fenntartható fejlődés kihívásával is szembe kell nézniük. Az Európai Bizottság nemrég elfogadott, „A városi környezetre vonatkozó tematikus stratégia” (Thematic Strategy on the Urban Environment) címü dokumentuma szerint:

„A legtöbb város olyan közös környezetvédelmi alapproblémákkal küzd, mint a városi levegö rossz minösége, a növekvő jármüforgalom és torlódások, a nagy háttérzaj, az épített környezet gyenge minősége, az elhagyott földek, az üvegházhatású gázok kibocsátása, a tagolatlan városi terjeszkedés/szétterülés, a nagy mennyiségü hulladék és szennyvíz kezelése. ... a legsikeresebb helyhatóságok a városi környezeti kérdések menedzselésében integrált szemléletet alkalmaznak, ami hosszú távú és stratégiai cselekvési tervek elfogadását jelenti. ... A helyi, regionális, országos vagy európai szinten meghatározott (pl. területhasználatra, zajszintre, levegöminőségre vonatkozó) kötelezettségeknek hatékonyabban meg lehet felelni helyi szinten, ha ezeket a helyi stratégiai irányítási keretbe integrálják." (European Comission $2006,3)$ 
Tosics Iván : Nagyvárosi kormányzás : A város és környéke együttmüködése. Külföldi példák és a hazai relevancia.

Tér és Társadalom 22. évf. 2008/1.

A nagyvárosi térségekben tehát közös kötelezettség-vállalásokra is szükség van. A városrégió sok esetben a legmegfelelőbb az olyan problémákra adandó válaszok kidolgozására, mint például a szennyvízkezelés, a légszennyezés stb.

A nagy kiterjedésü funkcionális városi térségek fenntartható fejlődése csak átfogó közpolitikák alapján képzelhetỏ el. A területi koordináció történhet közvetlenül, az ágazati politikákon (közlekedés, hulladék, víz stb.) keresztül, vagy pedig közvetve, a pénzügyi kiegyenlítésen és adózáson keresztül (Tosics 2004, 71). A legbonyolultabb és leginkább átpolitizált kérdésekben - mint pl. a közös közlekedéspolitika, hulladékkezelés vagy az adókiegyenlítés - sokkal nehezebb területi megállapodást elérni, mint például a gazdasági versenyképesség javítására vonatkozóan.

Azokban az országokban, ahol a decentralizáció és a hatalom átruházás széles körủ volt és az önkormányzatok szinte teljesen függetlenné váltak, a városi térségek további nehézségekkel néznek szembe a 'szabályozási' típusú megállapodások terén. Amennyiben az együttmüködési kultúra is hiányzik, a városrégió-együttműködés szempontjából szinte reménytelen helyzetek alakulhatnak ki - ahogy ezt néhány kelet-kőzép-európai országban láthatjuk (Tosics 2005a).

A tartós siker érdekében a városrégióknak a pozitív, illetve szabályozási feladatokat egyaránt meg kell oldaniuk, miközben a körülmények nagyon különbözőek az egyes országokban. A versenyképességi megállapodások létrejötte a legtöbb országban a város-térségben található önkormányzatokon (és más érintett résztvevőkön) múlik. A szabályozási kérdésekre vonatkozóan ezzel szemben sok a 'külső' feltétel, és ezek nagyon különbözőek az önkormányzatok teljes függetlenségétől a közszolgáltatások némelyikének kötelezö, magasabb szintủ, koordinált szabályozásáig terjedő spektrumban.

\section{A nagyvárosi térségek és a többszintü kormányzási struktúrák a METROGOV városokban}

A METROGOV projektben nyolc európai város vett részt (Köln, Frankfurt, Birmingham, Glasgow, Milánó, Malmő, Lille, Budapest). Ez a városi kör megfelelő alapot szolgáltat egy európai szintủ eszmecseréhez a városrégió témájáról, mivel minden alaptípust leképez az európai országok ,regionalizáció/decentralizáció” szerinti tipológiájából. A városok mai helyzetét jellemzi, hogy egyiknek sincsenek stabil adminisztrativ mechanizmusai a városrégió szintjén, azonban mindegyikben vannak formális vagy informális törekvések az együıttmüködés javítására ezen a szinten.

\section{A meglévö többszintü kormányzási struktúrák és a városrégió}

Az 1. táblázat áttekintést ad a meglévő többszintủ kormányzási struktúrákról és a városrégió-szintroól a $\mathrm{METROGOV}$ városokban. $\mathrm{Az}$ első oszlopban a város maga, az utolsóban pedig a város feletti közigazgatási szint (tartomány, régió stb.) szerepel. A középső két oszlop a városrégió alternatív definíciói szerinti információt tartalmazza: a második a városrégió szükebb definícióját, a funkcionális városi térséget veszi ala- 
Tosics Iván : Nagyvárosi kormányzás : A város és környéke együttmüködése.

pul, a harmadik oszlop pedig a tágabb meghatározást (a gazdasági együttmúködés és/vagy befolyás területét). Sok esetben több definíció alapján találhatók információk, amikor az adott térség/szint esetében több definíciós alternatíva létezik.

\section{TÁBLÁZAT}

A meglévö kormányzási berendezkedés és a potenciális városrégiók a nyolc METROGOV városban (Existing Governance Structures and the Potential City-region Areas in the Eight METROGOV Cities)

\begin{tabular}{|c|c|c|c|c|}
\hline Város & $\begin{array}{c}\text { A város } \\
\text { (önkormányzat) } \\
\text { szintje }\end{array}$ & $\begin{array}{l}\text { Potenciális város- } \\
\text { régió-térség } \\
\text { (szűkebb definició) }\end{array}$ & $\begin{array}{c}\text { Gazdasági befolyás } \\
\text { térsége } \\
\text { (tágabb definició) }\end{array}$ & $\begin{array}{c}\text { A következö } \\
\text { közigazgatási } \\
\text { szint }\end{array}$ \\
\hline Köln & $\begin{array}{l}\text { Köln Önkor- } \\
\text { mányzata } \\
\text { Státusz: válasz- } \\
\text { tott önkormány- } \\
\text { zat } \\
\text { Nagyság: } \\
986 \text { ezer fó }\end{array}$ & $\begin{array}{l}\text { Régió: Köln-Bonn, } \\
\text { Köln + } 50 \text { önkormány- } \\
\text { zat } \\
\text { Státusz: önkéntes } \\
\text { Nagyság: } 3 \text { millió fö }\end{array}$ & $\begin{array}{l}\text { Európai Nagyvárosi } \\
\text { Régió (Metropolitan } \\
\text { Region): Rajna- } \\
\text { Ruhr } \\
\text { Státusz: nem létezó } \\
\text { Nagyság: } 8 \text { millió fó }\end{array}$ & $\begin{array}{l}\text { Észak-Rajna- } \\
\text { Vesztfália } \\
\text { Választott } \\
\text { regionális } \\
\text { kormányzat } \\
\text { Nagyság: } \\
18 \text { millió fó }\end{array}$ \\
\hline Frankfurt & $\begin{array}{l}\text { Frankfurt Ön- } \\
\text { kormányzata } \\
\text { Státusz: válasz- } \\
\text { tott önkormány- } \\
\text { zat } \\
\text { Nagyság: } \\
647 \text { ezer fö }\end{array}$ & $\begin{array}{l}\text { a) Tervezési társulás: } \\
\text { Frankfurt Rajna-Majna } \\
\text { Frankfurt + } 74 \text { önkor- } \\
\text { mányzat } \\
\text { Státusz: jogilag elöírt } \\
\text { regionális tervezés } \\
\text { Nagyság: } 2,2 \text { millió fó } \\
\text { b) Dél-Hessen köz- } \\
\text { igazgatási terület } \\
\text { Frankfurt + } 186 \text { ön- } \\
\text { kormányzat } \\
\text { Státusz: közigazgatási } \\
\text { funkciók } \\
\text { Nagyság: } 3,8 \text { millió fố }\end{array}$ & $\begin{array}{l}\text { Nagyvárosi régió: } \\
\text { Frankfurt Rajna- } \\
\text { Majna } \\
\text { Frankfurt + } 444 \\
\text { önkormányzat } \\
\text { Státusz: informális, } \\
\text { nincs saját költség- } \\
\text { vetés } \\
\text { Nagyság: } \\
5,3 \text { millió fó }\end{array}$ & $\begin{array}{l}\text { Hessen tarto- } \\
\text { mány: } \\
\text { Választott } \\
\text { regionális } \\
\text { kormányzat } \\
\text { Nagyság: } \\
6,1 \text { millió fó }\end{array}$ \\
\hline $\begin{array}{l}\text { Birming- } \\
\text { ham }\end{array}$ & $\begin{array}{l}\text { Birmingham } \\
\text { Önkormányzata } \\
\text { Státusz: válasz- } \\
\text { tott önkormány- } \\
\text { zat } \\
\text { Nagyság: } \\
977 \text { ezer fö́ }\end{array}$ & $\begin{array}{l}\text { Birmingham és } 7 \\
\text { önkormányzat } \\
\text { Státusz: informális } \\
\text { társulás } \\
\text { Nagyság: } 2,7 \text { millió fó }\end{array}$ & $\begin{array}{l}\text { Birmingham és } 20 \\
\text { önkormányzat („,op- } \\
\text { timális” városrégió) } \\
\text { Státusz: még nem } \\
\text { létező } \\
\text { Nagyság: } 3,5 \text { millió fó }\end{array}$ & $\begin{array}{l}\text { West Midlands } \\
\text { Régió } \\
\text { Státusz: közig. } \\
\text { régió } \\
\text { Nagyság: } \\
\text { 5,3 millió fố }\end{array}$ \\
\hline Glasgow & $\begin{array}{l}\text { Glasgow Ön- } \\
\text { kormányzata } \\
\text { Státusz: válasz- } \\
\text { tott önkormány- } \\
\text { zat } \\
\text { Nagyság: } \\
580 \text { ezer fö }\end{array}$ & $\begin{array}{l}\text { a) CVCPP: Glasgow és } \\
7 \text { önkormányzat } \\
\text { Státusz: önkéntes } \\
\text { tervezési társulás } \\
\text { Nagyság: } 1,75 \text { millió fó } \\
\text { b) Glasgow Nagyváro- } \\
\text { si Térség: Glasgow + } \\
11 \text { önkormányzat } \\
\text { Státusz: korábbi regio- } \\
\text { nális tanács területe } \\
\text { Nagyság: } 2,2 \text { millió fó }\end{array}$ & & $\begin{array}{l}\text { Skócia } \\
\text { Választott } \\
\text { parlament } \\
\text { Nagyság: } \\
5 \text { millió fó }\end{array}$ \\
\hline
\end{tabular}


Tosics Iván : Nagyvárosi kormányzás : A város és környéke együttmüködése.

Külföldi példák és a hazai relevancia.

Tér és Társadalom 22. évf. 2008/1.

TÉT XXII. évf. 2008 a 1

Nagyvárosi kormányzás ...

13

\begin{tabular}{|c|c|c|c|c|}
\hline Város & $\begin{array}{c}\text { A város } \\
\text { (önkormányzat) } \\
\text { szintje }\end{array}$ & $\begin{array}{l}\text { Potenciális város- } \\
\text { régió-térség } \\
\text { (szükebb definíció) }\end{array}$ & $\begin{array}{c}\text { Gazdasági befolyás } \\
\text { térsége } \\
\text { (tágabb definició) }\end{array}$ & $\begin{array}{c}\text { A következó } \\
\text { közigazgatási } \\
\text { szint }\end{array}$ \\
\hline Milánó & $\begin{array}{l}\text { Milánó Őnkor- } \\
\text { mányzata } \\
\text { Státusz: választott } \\
\text { önkormányzat } \\
\text { Nagyság: } \\
\text { 1,26 millió fó }\end{array}$ & $\begin{array}{l}\text { a) Jogi definíció: Milá- } \\
\text { nó+ } 138 \text { őnkormányzat } \\
\text { Státusz: nem müködik } \\
\text { b) Milánó tartomány } \\
\text { (Milánó + } 188 \text { önkor- } \\
\text { mányzat) } \\
\text { Státusz: közigazgatási } \\
\text { Nagyság: 3,7 millió fő }\end{array}$ & $\begin{array}{l}\text { Gazdasági térség } \\
\text { Milánó + } 1000 \\
\text { önkorm. } \\
\text { Státusz: nem múködik } \\
\text { Nagyság: } 6 \text { millió fö }\end{array}$ & $\begin{array}{l}\text { a) Milánó } \\
\text { tartomány } \\
\text { (Milánó + } 188 \\
\text { önkormányzat) } \\
\text { Státusz: köz- } \\
\text { igazgatási } \\
\text { Nagyság: } \\
\text { 3,7 millió fó } \\
\text { b) Lombardia } \\
\text { Státusz: választott } \\
\text { önkormányzat } \\
\text { Nagyság: } \\
\text { 9,1 millió fó }\end{array}$ \\
\hline Malmö & $\begin{array}{l}\text { Malmó Önkor- } \\
\text { mányzata } \\
\text { Státusz: választott } \\
\text { önkormányzat } \\
\text { Nagyság: } \\
270 \text { ezer fó }\end{array}$ & $\begin{array}{l}\text { Önkéntes együttmükơ- } \\
\text { dés } \\
\text { SSSV: Malmő + } 10 \\
\text { önkormányzat } \\
\text { Státusz: önkéntes szö- } \\
\text { vetség } \\
\text { Nagyság: } 590 \text { ezer fö }\end{array}$ & $\begin{array}{l}\text { a) munkaerőpiac } \\
\text { területe Malmö + } 24 \\
\text { önkorm. } \\
\text { Nagyság: } 970 \text { ezer fó } \\
\text { b) Ôresund régió } \\
\text { Malmö + } 79 \text { önkorm., } \\
\text { határon átnyúló } \\
\text { Informális együttmü- } \\
\text { ködés } \\
\text { Nagyság: } 3,6 \text { millió fó }\end{array}$ & $\begin{array}{l}\text { Skane régió } \\
\text { Malmó + } 32 \\
\text { önkorm. } \\
\text { Státusz: válasz- } \\
\text { tott regionális } \\
\text { parlament } \\
\text { Nagyság: } \\
1,2 \text { millió fó }\end{array}$ \\
\hline Lille & $\begin{array}{l}\text { a) Lille Önkor- } \\
\text { mányzata } \\
\text { Státusz: választott } \\
\text { önkormányzat } \\
\text { Nagyság: } \\
227 \text { ezer fó } \\
\text { b) „Communauté } \\
\text { Urbaine”: Lille + } \\
84 \text { önkormányzat } \\
\text { Státusz: törvény } \\
\text { szerint létrehozott } \\
\text { helyi önkormányzat } \\
\text { Nagyság: } \\
1,09 \text { millió fó } \\
\text { c),arrondissment": } \\
\text { Lille + } 125 \text { önkorm } \\
\text { Státusz: törvény } \\
\text { szerint létrehozan- } \\
\text { dó közigazgatási- } \\
\text { statisztikai } \\
\text { Nagyság: } \\
1,18 \text { millió fö }\end{array}$ & $\begin{array}{l}\text { a) Communauté } \\
\text { Urbaine: Lille + } 84 \\
\text { önkorm. } \\
\text { Státusz: törvény szerint } \\
\text { létrehozandó helyi } \\
\text { önkormányzat } \\
\text { Nagyság: } \\
1,09 \text { millió fö́ } \\
\text { b) Határon átnyúló } \\
\text { térség: Lille + } 150 \\
\text { önkormányzat } \\
\text { Státusz: formális Lille } \\
\text { Eurodistrict } \\
\text { Nagyság: } 1,9 \text { millió fó }\end{array}$ & $\begin{array}{l}\text { Nagyvárosi Térség: } \\
\text { Lille }+620 \text { önkor- } \\
\text { mányzat, határon } \\
\text { átnyúló } \\
\text { Státusz: Önkéntes, } \\
\text { informális } \\
\text { Nagyság: } 3,6 \text { millió fổ }\end{array}$ & $\begin{array}{l}\text { a) Nord - Pas de } \\
\text { Calais (F) } \\
\text { Státusz: válasz- } \\
\text { tott regionális } \\
\text { tanács } \\
\text { Nagyság: } \\
4 \text { millió fó } \\
\text { b) Flandria (B) } \\
\text { Választott } \\
\text { regionális tanács } \\
\text { Nagyság: } \\
6 \text { millió fó } \\
\text { c) Wallonia(B) } \\
\text { Választott } \\
\text { regionális } \\
\text { tanács, francia } \\
\text { megyék és belga } \\
\text { tartományok } \\
\text { Nagyság: } \\
3,5 \text { millió fó }\end{array}$ \\
\hline Budapest & $\begin{array}{l}\text { Budapest Önkor- } \\
\text { mányzata } \\
\text { Státusz: választott } \\
\text { önkormányzat } \\
\text { Nagyság: } \\
\text { 1,7 millió fö }\end{array}$ & $\begin{array}{l}\text { Budapesti agglomeráció } \\
\text { Státusz: (közigazgatási)- } \\
\text { statisztikai egység } \\
\text { Nagyság: } 2,4 \text { millió fổ }\end{array}$ & $\begin{array}{l}\text { Gazdasági térség } \\
\text { Budapesti térség a } \\
\text { környezỏ nagyobb } \\
\text { városokkal bezárólag } \\
\text { (,csapágyvárosi gyứnu"') } \\
\text { Státusz: nem létező } \\
\text { Nagyság: } 4 \text { millió fỏ }\end{array}$ & $\begin{array}{l}\text { Közép- } \\
\text { magyarországi } \\
\text { régió } \\
\text { Stả́tusz: közigaz- } \\
\text { gatási-statisztikai } \\
\text { régió } \\
\text { Nagyság: } \\
2,9 \text { millió fố }\end{array}$ \\
\hline
\end{tabular}

Forrás: Homan-Howl-Tosics $(2007,36)$. 
Tosics Iván : Nagyvárosi kormányzás : A város és környéke együttmüködése. Külföldi példák és a hazai relevancia.

Tér és Társadalom 22. évf. 2008/1.

Az 1. táblázat azt sugallja, hogy minden város különböző a város, a városrégió, illetve a következő közigazgatási szint relatív pozícióját tekintve. A 2. táblázatból, amely a különböző szintek lakosságának arányát mutatja, kiderül, hogy ez nem így van.

\section{TÁBLÁZAT}

A városrégiók és közigazgatási régiók nagysága a városokhoz képest a nyolc METROGOV város esetében

(Ratios of Population Numbers in the Different City-region Areas Compared to the City, in the Eight METROGOV Cities)

\begin{tabular}{lcccc}
\hline \multirow{2}{*}{$\begin{array}{c}\text { Város } \\
\text { Város }\end{array}$} & \multicolumn{3}{c}{$\begin{array}{c}\text { A város lakosságához viszonyitott nagyság } \\
\text { (arány-\%) }\end{array}$} \\
\cline { 3 - 5 } & \begin{tabular}{c} 
(ezer fó) \\
\cline { 3 - 5 }
\end{tabular} & $\begin{array}{c}\text { Szúkebb } \\
\text { városrégió- } \\
\text { térség }\end{array}$ & $\begin{array}{c}\text { Tágabb } \\
\text { városrégió- } \\
\text { térség }\end{array}$ & $\begin{array}{c}\text { Következö } \\
\text { közigazgatási } \\
\text { szint }\end{array}$ \\
\hline Köln & 986,0 & 3,0 & 8,1 & 18,3 \\
Frankfurt & 647,0 & $3,4-5,9$ & 8,2 & 9,4 \\
Birmingham & 977,0 & 2,8 & 3,6 & 5,4 \\
Glasgow & 580,0 & 3,0 & 5,2 & 8,6 \\
Milánó & 1260,0 & 2,9 & 4,8 & 7,2 \\
Malmő & 270,0 & 2,2 & $3,6-13,3$ & 4,3 \\
Lille & 227,0 & 6,2 & 15,9 & 17,6 \\
Lille* & 1090,0 & 1,7 & 3,3 & 3.6 \\
Budapest & 1700,0 & 1,4 & 2,4 & 1,7 \\
\hline
\end{tabular}

* Lille-t a „Communauté Urbaine" szintjén értelmezve.

Forrás: Homan-Howl-Tosics $(2007,35)$.

A METROGOV városok több mint fele hasonló képet mutat, ha a városrégiós térség és a város lakosságának arányát nézzük: a kisebb városrégió lakossága (funkcionális városi térség) 3-3,5-szerese a városénak, míg a nagyobb városrégió (a gazdasági befolyás térsége) 4-8-szorosa. A tágabb definícióval meghatározott városrégió lakossága általában kisebb a következö (regionális) közigazgatási szint népességénél.

Lille és Malmő kivételes értéke a határokon átnyúló kapcsolatokban, illetve térségeik policentrikus jellegében rejlik, Budapesté pedig abban, hogy a város maga nagyon nagy (különösen, ha az ország egészéhez viszonyítjuk, hiszen a teljes lakosság 17\%-a él a fövárosban).

$\mathrm{Az}$ összes METROGOV város esetében a városrégió a kormányzásnak egy ủjabb szintjét jelentené, amelynek be kellene férnie a már amúgy is túlzsúfolt igazgatási struktúrába. Mindenhol legalább négy meglévö szint van: a város, a régió, a nemzetállam és Európa, melyek mindegyike különbözö politikákkal és stratégiákkal rendelkezik, amelyeket összhangba kell hozni a városrégiós szemlélettel. A meglévő struktúrák átalakítása törvényhozásbeli változtatásokat tehet szükségessé, ezért nehézkes és hosszadalmas lehet. 
Tosics Iván : Nagyvárosi kormányzás : A város és környéke együttmüködése. Külföldi példák és a hazai relevancia.

Tér és Társadalom 22. évf. 2008/1.

\section{Városrégió-szintü funkciók a többszintü kormányzási rendszerben}

A METROGOV projekt során három különböző funkció (stratégiai tervezés, tömegközlekedés és hulladékelhelyezés) tekintetében kerültek összehasonlításra a városok, aszerint, hogy ezek a funkciók milyen mértékben teljesülnek a városrégiós területükön.

A feltevés az volt, hogy egyetértésre jutni a stratégiai tervezésben a legkönnyebb, a tömegközlekedést illetően nehezebb, és a hulladékelhelyezés tekintetében a legnehezebb (ez utóbbi szabályozó funkció, ahol erós a NIMBY-effektus).

A szerzett tapasztalatok nem erősítették meg teljes mértékben a feltevést: jónéhány város esetében a tömegközlekedési együttmúködés városrégiós szinten fejlettebb, mint a közös stratégiai tervezés, különösen ott, ahol a tömegközlekedési együttmüködést regionális (vagy nemzeti) szinten kezdeményezik és szervezik meg. Ezekben a városi térségekben a stratégiai tervezési együttműködés - amely sokkal inkább alulról építkezö kezdeményezés kellene hogy legyen - kevésbé fejlett, mivel kevésbé sürgetőnek tűnik az önkormányzatok számára.

E megjegyzéstől eltekintve világos, hogy a stratégiai tervezés és a tömegközlekedés alkotja mindenfajta városrégiós kapcsolat minimális tartalmát. A hulladékelhelyezés nem tartozik a városrégiós funkciók közé, mivel ez (más infrastrukturális szolgáltatáshoz hasonlóan) kifejezetten technikai jellegủ, megoldható olyan önkormányzatok egyfunkciós partnersége keretében, amelyek nem feltétlenül tartoznak a városrégiós területhez. Az effajta infrastrukturális szolgáltatásokra vonatkozó területi együttmüködési megállapodások ugyanakkor fontosak, föként a fenntartható városfejlesztés szempontjából. Emiatt az önkormányzatok infrastrukturális szolgáltatási együttmúködése szintén a városrégiós partnerséghez való hozzájárulásnak tekintendő, habár nem ez a fő motiváló erő.

„Optimális” forgatókönyv esetén a szabályozó funkciókat bizonyos mértékig városrégiós szinten vezérlik (de nem feltétlenül pontosan ezen a területi alapon szervezik), míg a pozitív, mindkét fél számára előnyös funkciókat minimum ezen a szinten, sőt akár a szélesebb városrégiós területen is teljesíthetik, lefedvén a város teljes gazdasági befolyási területét.

\section{Az eredményes városrégiók jellemzöi}

\section{A városrégiók különböző kormányzási modelljei}

A városok és a régiók egyre erősödő nemzetközi versenyének feltételei között a kormányzás és a vezetés kritikus jelentőségủ tényezővé válik a városrégiók fejlesztésében (Clark 2005). 
Tosics Iván : Nagyvárosi kormányzás : A város és környéke együttmüködése. Külföldi példák és a hazai relevancia.

Tér és Társadalom 22. évf. 2008/1.

$\mathrm{Az}$ Eurocities Kormányzati Munkacsoport európai nagyvárosokban végrehajtott felmérésre épülỏ szakmai anyaga szerint a városrégiók két fö módon nyerhetik el demokratikus legitimitásukat:

- Indirekt módszer. Az önkormányzatok maguk jelölik ki választott tagjaik közül azokat, akiket a városrégió kormányzatába delegálnak. Az esetek többségében ez a megközelítés érvényes.

- Közvetlen választással, a városrégió lakosságának körében az általános választójog alapján szervezett választás keretében.

A városrégió vezetỏjének kiválasztására is többféle mechanizmus lehetséges:

- A városrégiós gyúlés szavazása,

- Törvény általi kinevezés,

- Vezetés rotációs alapon,

- Az elnök automatikusan a városrégió legnagyobb városából érkezik,

- Nincs elnöki tisztség.

A városrégiók többségében kettős kormányzati rendszer müködik, amennyiben a politikai szintet egy tanácsadó szerepủ tisztségviselői pillér támogatja. Az informális városrégiók esetében is előfordul, hogy megállapodások körvonalazzák a résztvevők szerepköreit, bár e struktúrák jogilag nem kötelező érvényúek és a részvétel önkéntes. Magukat a megbeszéléseket azonban sokszor nagyon is komolyan veszik (Glasgowban például jegyzőkönyvet vezetnek, és jelen van az illetékes skót miniszter).

A városrégiók jogosultságai nagymértékben különbözhetnek. Lyon és Lille esetében a Communauté Urbaine telekvásárlási és adóemelési (iparüzési és hulladékkezelési ađó) jogosultsággal rendelkezik; jelentős a költségvetése és önkormányzati igazgatási szervként jár el. Barcelonában a környezetvédelmi és közlekedési testületek világosan meghatározott felelösségi körökkel és némi pénzügyi erőforrással rendelkeznek. Hasonló a helyzet Birmingham városrégiós közlekedési testülete esetében. Viszont a barcelonai, városfejlődési kérdésekkel foglalkozó városrégiós testület - hasonlóan az újabbkeletü testületekhez, például Milánóban és Frankfurtban - kevesebb eröforrással és nem pontosan körvonalazott jogosultságokkal rendelkezik. A Birminghami Városrégió példája is mutatja, hogy ezek az újabb testületek bizonytalan pénzügyi és jogi keretek között müködnek, befolyásukat a szakmapolitikákkal és a prioritásokkal kapcsolatos közös lobbizással, valamint az erőforrásokra és a projektekre történő közös pályázással fejtik ki.

Egyes esetekben a polgármesterek felügyelik a városrégió müködésének adott részét, majd beszámolnak a városrégiós partnerségben részt vevö többi polgármesternek. Máshol a városrégió költségvetést és éves beszámolót köteles benyújtani a Kormányzó Tanácsnak és a Közgyủlésnek, illetve tanácsadó testület számol be a városrégió mindegyik tanácsának. A legformalizáltabb megközelítés Franciaországban tapasztalható, ahol az éves költségvetést és tevékenységi jelentést a Tanács szavazza meg, a nemzeti kormány kíséri figyelemmel és a Chambre Régionale des Comptes felügyeli. Ennek a példának az értékét azonban csökkenti, hogy szakértők szerint a Communauté Urbaine nem tekinthető „normál” európai városrégiónak, 
Tosics Iván : Nagyvárosi kormányzás : A város és környéke együttmüködése. Külföldi példák és a hazai relevancia.

Tér és Társadalom 22. évf. 2008/1.

TÉT XXII. évf. 2008 - 1

Nagyvárosi kormányzás ...

mivel szerepe inkább csak az Európa-szerte szokásos városi szint újrateremtése az igen szegmentált franciaországi településstruktúrában.

\section{A városrégiók intézményi és pénzügyi viszonyai}

A városrégiók csak a politikából nem élnek meg: valóságos, tárgyi erőforrásokra van szükségük, ha nemzetgazdaságuk és Európa motorjaiként kívánnak prosperálni. Ezek az erőforrások többféle forrásból származhatnak:

1) Normatív központi kormányzati erőforrások: Nagy-Britanniában, illetve más európai országokban folyamatosan tárgyalt téma a fiskális jogkör átruházása a városrégiókra (Marshall-Finch 2006). A városrégióknak saját bevételi forrásokkal kellene rendelkezniük, elkerülve, hogy költségvetésük minden elemét a központi kormányzat határozza meg. Carley szerint $(2000,287)$ elegendő mértékủ jogkör-átruházás nélkül a helyi hatóságok képtelenek ,útjára indítani az innovációt partnerségeikben, illetve saját maguk és partnereik számára stratégiai szerepet meghatározni és megvalósítani".

2) Fejlesztés-finanszírozási erőforrások: A jogkör-átruházás által nyújtott hosszú távú megoldások mellett a „projekt-alapú” vagy átmeneti finanszírozási áramlásokkal támogatható a városrégiós munka. A METREX hálózat azt szeretné elérni, hogy a Strukturális Alapokat városrégiós szinten kezeljék. Carley $(2000,287)$ - különösen a városrehabilitáció tárgyalásakor - azt indítványozza, hogy ,... minden érintett, tehát a központi kormányzat, a helyi hatóságok és egyéb köz- és magánképviseletek együttmüködjenek egy integráltabb és innovatívabb megközelítés érdekében a városrehabilitációs partnerségek finanszírozását tekintve."

\section{Partnerség a magánszektorral}

Jelentős tapasztalatok vannak arra nézve, hogy a magánszektor mennyire központi szerepet játszik a városrégiós partnerség müködtetésében (pl. Carley 2000; Leibovitz 2003; Marshall-Finch 2006). Az üzleti szféra értelmes bevonása különösen kritikus jelentőségủ a versenyképesség javitásában. A köz- és a magánszféra partnerségének múködtetési sikere azonban mindkét oldalon az eredményes és hatékony döntéshozatali folyamattól függ.

A kölcsönös gyanakvás persze megmaradhat a magánszektor szervezetei és a helyi önkormányzat között. Az üzleti szféra hajlamos úgy tekinteni a helyi önkormányzatot, hogy az szük látókörü, védekező hozzáállású és nincs stratégiai perspektívája. A helyi önkormányzat pedig hajlamos úgy tekinteni a magánszektort, hogy az csak saját érdekeivel foglalkozik és túlegyszerüsíti az értelmes partnerség kialakításában rejlö kihívásokat. Kihívást jelent a sokféle érdek képviselete, különösen akkor, ha jelentős a vállalkozások közötti verseny (Leibovitz 2003). Carley szerint $(2000,283)$ „Eredményes, hosszan tartó üzleti részvételre akkor kerül sor, ha a vállalkozások képviselői szerveződésbe tömörülnek a partnerség létesítését megelö- 
Tosics Iván : Nagyvárosi kormányzás : A város és környéke együttmüködése. Külföldi példák és a hazai relevancia.

Tér és Társadalom 22. évf. 2008/1.

18 Tosics Iván

TÉT XXII. évf. 2008

zően. Ez például Kereskedelmi Kamarán vagy 'a célra alkalmas' külön szervezeten keresztül történhet." Ebben a vonatkozásban jelentősen eltérőek a szabályozások az európai országokban: Franciaországban például kötelező a kereskedelmi kamarai tagság, míg Nagy-Britanniában és Magyarországon nem.

A városrégió, kevésbé formalizált jellegénél fogva az egyetlen olyan kormányzati szint, ahol lehetőség nyílik a magánszférával folytatott nyitott partnerségre. A magánszektor főbb szereplői közötti szoros koordináció olyan helyzetekhez vezethet, hogy a magánszektor kezdeményező szerepet játszhat a városrégiós szintủ együttmüködés elösegitésében, ahogyan az Lille és Frankfurt esetében is történt.

A magánszektor bevonása a városrégiós partnerségbe nem egyszerü feladat. Egy nyołc nagyvárosi régiót felölelö nagyon friss EURICUR-tanulmány szerint (van den Berg et al 2007) meglepően alacsony volt a magánszektornak az elemzett projektekben való részvétele, és fơként a projektek megvalósitási fázisára korlátozódott. Nem találtak példákat stratégiaibb jellegü partnerségekre állami és magánszervezetek között.

\section{Az európai tapasztalatok összefoglalása: következtetések és ajảnlások}

\section{A városrégió a versenyképesség és a fenntarthatóság hajtómotorja}

A városok és a körülöttük lévő területek közötti valós együttmüködés fontos cél, nemcsak a helyi körülmények javítása, hanem az európai fejlődés versenyképesebbé és fenntarthatóbbá tétele érdekében is.

A városrégiós együttmüködés lehetőségeit javítja az „új stílusư" regionális politikák terjedése, melyek keretében - szemben a „régi”, kiegyenlíto jellegủ regionális politikákkal - minden régió saját optimális szintjéig való növekedése a cél, mivel a nyitott nemzetközi gazdaság körülményei között nemzeti szinten ma már nincsen zéró összegủ játék. Ez azt jelenti, hogy egy régió sikere nem feltétlenül kell, hogy a többi régió lehetőségeinek beszükülését jelentse (Clark 2005).

A városrégiók sikeréhez elengedhetetlenül szükséges, hogy független és rugalmas eszközöket kapjanak a bevételteremtésre és -elköltésre, továbbá jogosultságot olyan döntések meghozatalára, amelyek érintik a városrégió és népessége jövőjét. Arról is gondoskodni kell, hogy a városrégiók növekedése kiegyenlített legyen mind környezetvédelmi, mind társadalmi szempontból. Mindennek érdekében aktív beavatkozásokra van szükség a városrégión belül, továbbá megfelelő döntéshozatali mechanizmusok érvénybe léptetésére.

A 21. századi új városrégiós együttműködési időszak különbözik a korábbitól. Nem valószínü, hogy a jelenlegi együttmüködési időszak eredménye ismét fixen körülhatárolt új közigazgatási szintek tömeges létrehozása lesz. Ma az a legvalószínübb, hogy a rugalmasabb együttmúködési modellek alapján lehet nagyobb területi egységeket létrehozni. Az új egységek nem rendelkeznek átfogó döntéshozatali jogosultsággal, céljuk, hogy vitafórumként szolgáljanak a részt vevő önkormány- 
zatok számára. A szélesebb körủ területi együttmủködés is teret hódít majd azokban a szektorokban, ahol minden partner nyer az együttmüködéssel.

Így az új együttműködési időszakban nagyobb hangsúly helyeződik a kormányzásra, a hálózatszerü struktúrákra és a rugalmasságra. A politikai és közigazgatási rendszerek különféle modelljei és az országok közötti geopolitikai különbségek nagyon eltérő körülményeket teremtenek a városrégiós együttmüködés létesítésére. Azokban az országokban, ahol minden hatalom a helyi önkormányzatok kezében van, kizárólag alulról építkező megközelítések lehetségesek. Más országokban, ahol a magasabb szintek (az országos szint, a közigazgatási régiók) rendelkeznek a legerősebb hatalommal, a városrégiók lehetőségei föként tőlük függenek. Európában nincs tehát kizárólagos, „egyméretes”, mindenki számára érvényes városrégiós együttmüködési modell, inkább karakterisztikák léteznek, amelyeket a környezetnek megfelelỏen adaptálnak.

A tapasztalatok szerint a „városrégió" megjelölés alatt kettős feladat értendő: a funkcionális városi területen belüli belső konfliktusok megoldása, illetve a bővebb városi terület gazdasági együttműködési lehetőségeinek kiaknázása. Az együttműködési kötelezettségvállalások önkéntes kialakítása a szükebb városrégió szintjén ritkán müködik jól és hosszan tartóan, itt erősebb együttmüködési keret kidolgozására is szükség van. A városrégióknak létre kell hozniuk azt a kapacitást, amellyel a zérusösszegü játékon túlra törhetnek, és egyaránt megteremthetik a versenyképes és fenntartható fejlődés feltételeit.

A struktúrált, koordinált, formális együttmüködési filozófia és a rugalmas megközelítés, a kreatív városrégiós kormányzás vonatkozásában a METROGOV munkája során új gondolat merült fel: a két különböző megközelítés egyidejü alkalmazása különböző térségi szinteken. A városrégiók térségileg szükebb és bővebb meghatározása közötti különbségtétel lehetővé teszi, hogy a városrégiók foglalkozzanak a funkcionális városi térségben felmerülö problémákkal, és ezzel egyidejủleg sokkal nagyobb területen fejlesszenek gazdasági együttmüködést. A szủkebb meghatározás együttmúködést jelent a közszolgáltatások széles körében (speciális célú szervek rugalmas vagy kötött térségi kialakításban) és a területfelhasználás tervezésében (a közös régiós szintủ stratégiai döntések végrehajtását garantáló mechanizmus, kötött területen). A szélesebb körủ együttmủködés célja a gazdasági tervezés és fejlesztés, esetleg néhány közszolgáltatás (közlekedés stb.) rugalmas, alulról építkező partnerség keretében.

A korábban tárgyalt alulról építkezỏ, illetve felülrỏl kialakított kezdeményezések kombinálhatók egymással, amennyiben kezdeményezések történnek a pozitív funkciók alulról építkező fejlesztésére, és ezzel párhuzamosan erőfeszítéseket tesznek a legfontosabb szabályozó funkciók felülröl való bevezetésére. A fixen körülhatárolt (szabályozó) és a rugalmasan körülhatárolt (mindkét fél számára kedvezỏ) együttmüködési megközelítés is kombinálható. Egy fixen körülhatárolt területen például olyan intézmény létesíthetö, amely együttmüködést kezdeményezhet különböző funkciók tekintetében, a terület alacsonyabb szintủ egységei közötti megállapodások alapján. 
Tosics Iván : Nagyvárosi kormányzás : A város és környéke együttmüködése. Külföldi példák és a hazai relevancia.

Tér és Társadalom 22. évf. 2008/1.

A fejlödés másik dimenziója az együttmüködési terület térségbeli kiterjesztése: ha a „központi városrégió” sikeres a magfunkciókat tekintve, sőt még néhány szabályozói jogkör tekintetében is, cél lehet egy „szélesebb városrégió” kialakítása, amely kis számú funkcióra korlátozódik, föként mindkét fél számára kedvezö alapon.

\section{A különbözö kormányzási szintek szerepe}

A városi önkormányzat szerepe

A helyi különbségek miatt minden városnak a maga módján kell kiépítenie a városrégiót. A városi hatóságnak - partnerségben más érdekelt felekkel a városrégiós szinten - el kell végeznie a helyi körülmények elemzését (a morfológiai városi terület, a funkcionális városi terület és a gazdasági együttmüködési terület elemzése és összehasonlítása). Ennek alapján - a környezö területek önkormányzataival és egyéb szereplöivel együtt - közös nagyvárosi fejlesztési tervet és többéves programot kell kidolgozniuk, amelyben a szủk, funkcionális városi térség-szintü városrégió és a szélesebb területen megvalósuló gazdasági együttműködés kialakítását célzó terv szerepel. Mindezeket a tevékenységeket be kell ágyazni a kialakuló nemzeti szintü városrégiós politikába.

A közszféra, az adminisztratív szereplők mellett be kell vonni más szereplőket, a lakosságot, a gazdaságot, a civil társadalmat. A jelenlegi helyi tisztségviselók legitimitása és elszámoltathatósága kisebb területi egységekre korlátozódik, és igen formális szinten valósul csak meg. A városrégiót vagy közvetlenül választott politikusok kell hogy képviseljék, vagy szabad akaratú partnerségek alapján - ami a demokrácia új formája. Az utóbbi esetben minimálfeltételeket kell megszabni, melyek lehetöséget nyújtanak az önkéntes folyamatokra, önkéntes alapon.

\section{A nemzeti és a regionális kormányzatok szerepe}

A sikeres városrégiós együttmüködéshez megfelelő nemzeti keretekre van szükség, fóleg a lehetóségek oldaláról. A nemzeti városrégiós napirendek elsősorban „pozitív árukra" kell, hogy vonatkozzanak, míg a negatív áruk (szabályozói kérdések) kezelését kormányzati megoldásokkal kell elvégezni a területi tervezés keretében.

Már léteznek példák Európában az effajta nemzeti politikákra: a Német Nagyvárosi Régió Napirend, Nagy-Britannia elgondolásai a városrégiók nemzetgazdasági megközelítésével kapcsolatban, valamint a francia felhívás a nagyvárosi együittmüködésre.

A pozitív napirendhez hasonlóan a szabályozói napirend esetében is szükséges, hogy nemzeti szinten figyelmet fordítsanak a városrégiókban rejlö lehetőségekre, csak más módon. A városi környezetvédelmi problémák - például a közlekedés okozta levegöszennyezés és széndioxid-kibocsátás - megoldására irányuló stratégiai válaszok keresésében a nemzeti stratégiák magukban kell, hogy foglalják - a helyi és a regionális hatóságok mellett - a városrégiókat is. 
Tosics Iván : Nagyvárosi kormányzás : A város és környéke együttmüködése. Külföldi példák és a hazai relevancia.

Tér és Társadalom 22. évf. 2008/1.

Fontos, hogy a városrégiós együttmúködés nemzeti és regionális szabályozása ne határozza meg konkrétan, hogy mit kell elvégezni, hanem iránymutatást adjon és ösztönözzön az együttmüködés kialakítására a városrégiókban. A lehetséges eszközök:

- Pénzügyi ösztönzök (több támogatás nyưjtható felülröl, ha együttmüködés létesül az elöírt kereten belül).

- Az együttmúködést akadályozó érdekek elleni küzdelem. A központi kormányzat maga ne állítson fel olyan kötelezettségeket, amelyek akadályozzák a területi, közösségek közti együttmüködést, sőt fontolja meg a meglévő jogszabályok e célból történő megváltoztatását.

A nemzeti szint feladata különösen az adminisztratív régiók problémájának kezelése, melyek esetleg ellenérdekeltek a városrégiók fejlesztését tekintve.

Az Európai Unió szerepe kritikus jelentőségű: mivel a nemzeti kormányoknak korlátozott lehetőségeik vannak a közigazgatási rendszerek megváltoztatására, Európa kell, hogy útmutatást adjon a városrégiós szint erősítéséhez. Számos szakértő egyetért azzal, hogy legalább a területi tervezést és a tömegközlekedés kezelését át kellene helyezni városrégiós szintre. Emellett az infrastruktúra fejlesztéséhez, a környezetvédelemhez és a társadalmi kohézió erösítéséhez is a városok és a körülöttük fekvő települések közös megközelítése szükséges. Mivel ezek nem mindkét fél számára elönyös helyzetek, az uniós szintröl érkező útmutatások és ösztönzők sokat segíthetnek az új elgondolásokkal szembeni helyi ellenállás legyozzésében.

\section{Felvetések a budapesti nagyvárosi térség kapcsán}

Budapest része volt a METROGOV projektnek, így rendelkezésre áll néhány öszszehasonlító adat. A szúkebb városrégió-térség (Budapest esetében a 81 településre kiterjedỏ budapesti agglomeráció) 2,4 millió lakosával a város lakosságának 1,4-szeresét teszi ki, ez a legkisebb arány a nyolc vizsgált térség között. A tágabb városrégió-térség (1. ábra) (Budapest esetében a 'csapágyvárosi gyủrü', amely a fövárost 60-80 km-es sugarú körben körülvevő középvárosokig terjed) mintegy 4 millió lakosával a város lakosságának 2,4-szeresét teszi ki, és ez szintén a legkisebb arány a nyolc vizsgált térség között. Az adatok is jelzik, hogy Budapest közigazgatási határai (az 1950-es kiterjesztés óta) jelentős részben tartalmazzák a funkcionális városi térség területét, és hogy a budapesti várostérség tipikusan egyközpontú, a fóváros által dominált.

Köztudott, hogy Budapest meglehetősen nagy az ország egészéhez viszonyítva, korábban 20\%-os, ma 17\%-os népességarányával. Ennek a ténynek nagy szerepe van abban, hogy a föváros környékének 1950-es becsatolása után évtizedekig hivatalosan nem kerülhetett szóba az, hogy a fỏváros vonzáskörzete bármilyen szintủ adminisztratív státuszt kapjon. Sőt, a hivatalos politika szintjén a föváros népességnövekedésének megállítása volt a cél, melynek érdekében különböző eszközökkel igyekeztek akadályozni a Budapestre való beköltözést. Ez csak részleges eredményekkel járt, a főváros lakossága mellett az agglomerációs gyürủ lakossága is gyor- 
Tosics Iván : Nagyvárosi kormányzás : A város és környéke együttmüködése. Külföldi példák és a hazai relevancia.

Tér és Társadalom 22. évf. 2008/1.

san növekedett - ezt a folyamatot nevezhetjük kelet-európai típusú szuburbanizációnak (Ekler-Hegedüs-Tosics 1980), amikor a városkörnyék növekedését még nem a városból kiköltözők, hanem az ország egyéb területeiröl oda törekvők, de oda beköltözni nem tudók okozzák. A rendszerváltás előtt csak statisztikai értelemben került megállapításra a budapesti agglomeráció, akkor még 44 településre kiterjedöen, és a hivatalos tervezés sem foglalkozott (egyetlen 1980-as évekbeli terv kivételével) Budapest és a környéke viszonyával.

\section{1. ÁBRA}

Budapest, az agglomeráció és a régió határai, valamint a csapágyvárosok (Territorial Delienation of Budapest, the Agglomeration Belt, the Administrative Region and the Surrounding City-ring)

KOZEP-MAGYARORSZAGI REGIO STRATLGIAI TERV

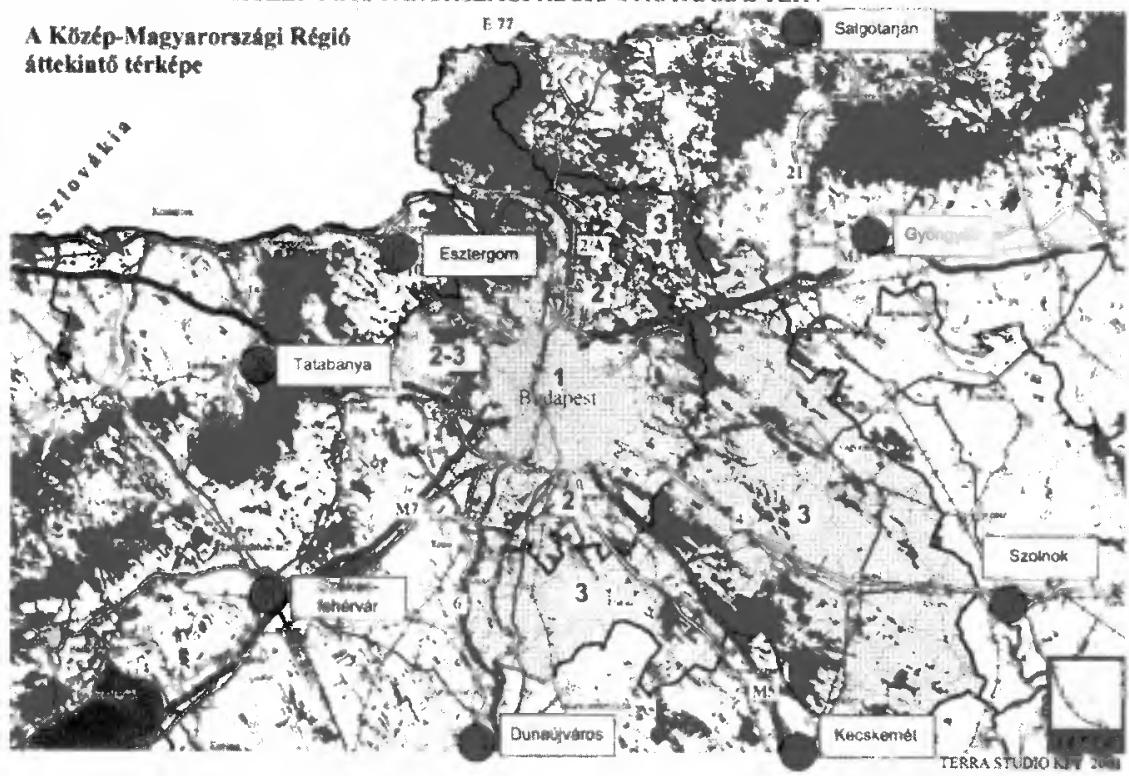

Forrás: Terra (2001).

A rendszerváltás után felgyorsult a városból való kiköltözés, ekkor a szuburbanizáció már a nyugati mintákat követte. Az erősen decentralizált jogiszabályozási környezet a nagyfokú települési önállósággal és a középszintủ kontroll teljes hiányával az agglomerációs övezet gyors növekedéséhez vezetett: zöldmezős ipartelepités, irodaépítés, bevásárlóközpontok és lakásépítés, szemben a városon belüli kiürülő barnamezővel, lerobbanó üzletekkel, elmaradó városrehabilitációval és gyorsan csökkenő városi lakossággal. Az évtized második felére megérett a felismerés, hogy valamit tenni kell a spontán folyamatok egyeduralma ellen. 1997-ben jött létre a Budapesti Agglomerációs Fejlesztési Tanács (BAFT), melynek az évtized végére sikerült kidolgoztatnia az agglomerációs fejlesztési koncepció szakmai anyagát és informális egyeztetéseket kezdeni a föváros és a megye vezetöi között 
egy kooperációs minimum elfogadtatása érdekében. A BAFT 1999-es megszüntetése véget vetett e folyamatoknak, a helyére lépő Közép-magyarországi régió (KMR) az agglomerációs problémáknak nem adott súlyúknak megfelelő jelentőséget. A KMR Fejlesztési Tanácsában a fốváros 2/3-os népességi súlyához képest elenyészö, 10-15\% körüli szavazati arányt kapott csak. Az évtized első felében a 'váljunk mielőbb szét' kérdés került a fókuszba, amit Pest megye azért forszírozott, mert így több EU-s fejlesztési pénzhez remélt jutni.

Az utóbbi 2-3 évben a helyzet fokozatosan normalizálódott, a KMR szétválása Budapestre és lyukas Pest megye régióra nem következett be ${ }^{4}$, és a KMR végre a térség tervezésével kezdett foglalkozni. Egy újabb pozitív lépés volt a BAFT újbóli létrehozása 2005 januárjában, a térségi fejlesztési célok összehangolása érdekében. A BAFT sokkal kiegyensúlyozottabb összetétele (4 fỏvárosi, 4 megyei és 1 országos delegált) Budapest számára kezdettől fogva sokkal elfogadhatóbb körülményeket jelentett a térség problémáinak tárgyalására. 2007 nyarára megszületett a Budapesti Agglomeráció Területfejlesztési Koncepciója és Stratégiai Programja (BAFT 2007), melynek kidolgozására összefogtak a térség főbb tervező mủhelyei (Ecorys Magyarország Kft., Városkutatás Kft., Főmterv Zrt., Pestterv Kft., Studio Metropolitana Kht.), akik a korábbi BAFT koncepciót is jegyezték. Megtörténtek az első lépések a Budapesti Közlekedési Szövetség (BKSZ) létrehozására is.

Ma ott tartunk, hogy a helyzet ugyan kicsit javult, de korántsem rózsás. A régiós szint erösítése, önkormányzati státuszának megadása a szükséges 2/3-os egyetértés hiányában elmaradt, és a KMR-en belül, Pest megyei oldalról újra megerösödnek a szétválás iránti érvelések. A BAFT tényleges hatáskör és pénzügyi eszközök nélküli szervezet, müködését a főváros és a KMR 10-10 millió Ft-os befizetése teszi lehetővé. A BKSZ tényleges kialakítása, a tarifaközösség létrehozása a távoli jövőbe tolódott. Szervezetek tehát léteznek ugyan a budapesti térségben, de tényleges kooperáció és olyan átfogó, fejlesztési célú dokumentum nincs, amelyet az egyes településeknek kötelező lenne figyelembe venniük.

Ha a rövid budapesti áttekintést összevetjük a nagyvárosi térségek múködésének korábban tárgyalt nemzetközi példáival, megállapíthatjuk, hogy a magyar példa a térségi kooperáció kialakításának igencsak a kezdeténél van egyelöre. A jogi szabályozás (Önkormányzati Törvény) és a meglévỏ intézményi rendszer (KMR) valójában nem jelent pozitív, ösztönző keretet a nagyvárosi térség fejlődésének. A BAFT ugyan lefedi a funkcionális városi térség egy részét (ma már korántsem az egészét), de sem jogosultságaiban, sem pénzügyi eszközeiben nem jelent erős kooperációs szintet. A tágabb nagyvárosi térség szintjén pedig semmilyen kooperáció, de még konzultáció sincs Budapest és a csapágyvárosi gyűrủ települései közöttt.

Budapestnek és a térség többi szereplőjének ebből a helyzetből nagyon hosszú utat kell megtennie a tényleges térségi kooperáció kialakítására, úgy a szủkebb funkcionális térben, mint a tágabb gazdasági befolyási övezetben. Az idő pedig sürget, mert az együttmúködés és az ezen alapuló, közös akaratot tükröző szabályozások és fejlesztési elképzelések hiányában a budapesti térség sem belsö problémáit nem tudja megoldani, sem pedig kedvező európai fejlódési potenciáljait nem tudja kihasználni. 
Tosics Iván : Nagyvárosi kormányzás : A város és környéke együttmüködése. Külföldi példák és a hazai relevancia.

Tér és Társadalom 22. évf. 2008/1.

\section{Jegyzetek}

${ }^{1}$ Ebből a szempontból kivételt képeznek a francia „,communautés urbaines”-ek, melyek nem kerültek felszámolásra.

2 A tanulmányban a nagyvárosok esetére szinonímaként használjuk a városi térség, város és kömyéke, városrégió kifejezéseket.

${ }^{3} \mathrm{Az}$ adott térségben szerepet játszó kormányzati, fontosabb nem-kormányzati és magánszervezetek vezetöit tömörítỏ csoportosulás.

${ }^{4}$ Jellemzó a viszonyokra, hogy Pest megye egyhangú közgyưlési határozatot hozott a KMR szétválása mellett, míg Budapest ugyancsak egyhangút ez ellen. A budapesti érvelés, miszerint funkcionálisan egybetartozó térséget nem szabad külön adminisztratív egységekre bontani (mert akkor felerősődik a versengés a kooperáció kárára) nem az érvelés kristálytiszta logikája és igazsága miatt kerekedett felül, hanem pusztán azért, mert a szétválással az ország egésze nem kapott volna több pénzt az EU-tól.

\section{Irodalom}

BAFT (2007) Budapesti Agglomeráció Terïletfejlesztési Koncepciója és Stratégiai Programja. www.baft.hu

Balducci, A.-Kunzmann, K.R.-Sartorio, F.S. (2004) Towards creative city-region govemance in Italy and Germany. - DISP. 158. 2-4. o.

Carley, M. (2000) Urban partnerships, govemance and the regeneration of Britain's cities. International Planning Studies. 3. 273-297. o.

Clark, G. (2005) City-Regional Development Agencies. www.citiesandregions.com

Ekler D.-Hegeduis J.-Tosics I. (1980) A városépités alkalmazott társadalmi gazdasági modelljének elméleti és módszertani kérdései. Kézirat. Budapesti Városépítési Tervező Vállalat, Budapest.

European Commission (2006) Thematic Strategy on the Urban Environment. Communication from the Commission to the Council and the European Parliament. COM(2005)718 final. Brusses.

Healy, P. (2004) Creativity and urban governance. - Policy Studies. 2. 87-102 . o.

Homan, J.-Howl, D.--Tosics, I. (2007) Urbact METROGOV Final Report. Birmingham.

Hooghe, L.-Marks, G. (2001) Types of multi-level govemance. - European Integration Online Papers. 11.

Jones, A.-Williams, L.-Lee, N.-Coats, D.-Cowling, M. (2006) Ideopolis: Knowledge City-Regions. The Work Foundation, London.

Kim, S.J. (2006) OECD Territorial Reviews: Why co-operation between cities and regions. Presentation at the Eurocities Economic Development Forum meeting, Budapest. 22-25 March, 2006.

Kreukels, A.M.J. (2000) Interkommunale Kooperation in den Niederlanden. - Heinz, W. (ed.) Stadt \& Region: Kooperation oder Koordination? Ein internationaler Vergleich. Schriften des Deutshen Instituts für Urbanistik, Band 93. Kohlhammer, Stuttgart. 423-496. o.

Kunzmann, K.R. (2004) An agenda for creative govemance in city-regions. - DISP. 158. 5-10. o.

Leibovitz, J. (2003) Institutional barriers to associative city-region governance: the politics of institutionbuilding and economic governance in "Canada's Technology Triangle". - Urban Studies. 13. 2613-2642. o.

Marshall, A.-Finch, D. (2006) City leadership: giving city-regions the power to grow. Centre for Cities, London.

METREX (2005) The network of European metropolitan regions and areas. www.eurometrex.org

NLGN (2006) Seeing the light: next steps for city-regions. NLGN, London.

OECD (2000) The reform of metropolitan governance. OECD Policy Brief, Organisation for Economic Co-operation and Development, Paris.

Parkinson, M. (2004) Competitive European cities: where do the Core Cities stand? ODPM, London.

Terra Stúdió Kft. (2001) Közép-Magyarországi Régió Stratégiai Terv. Budapest.

Tosics, I. (2004) European urban development: Sustainability and the role of housing. - Journal of Housing and the Built Environment. 19. 67-90. o.

Tosics, I. (2005a) City Development in Central and Eastem Europe Since 1990: the Impact of Intemal Forces. - Hamilton, F.E.I.-Dimitrowska-Andrews, K.-Pichler-Milanovic, N. (eds.) Transformation of Cities in Central and Eastern Europe. Towards Globalization. United Nations University Press, Tokyo. 44-78. o. 
Tosics Iván : Nagyvárosi kormányzás : A város és környéke együttmüködése.

Külföldi példák és a hazai relevancia.

Tér és Társadalom 22. évf. 2008/1.

Tosics, I. (2005b) Metropolitan co-operation as a precondition for international competitiveness. Special difficulties in preparing post-socialist cities for international competition: The case of Budapest. Giffinger, $\mathbb{R}$ (ed.) Competition between Cities in Central Europe: Opportunities and Risks of Cooperation. Road, Bratislava. 78-88. o.

Townsend, A. (2005) Multi-level governance in England. Background Paper for the Office of the Deputy Prime Minister, International Centre for Regional Regeneration and Development Studies, Durham University, Durham.

van den Berg, L.-van der Meer, J.-Otgaar, A.H.J-Speller, C.J.M. (2007) Empowering metropolitan regions through new forms of co-operation. New perspectives on metropolitan governance. EURICUR.

\section{CITY-REGION GOVERNANCE: THE COOPERATION BETWEEN THE CITY AND THE METROPOLITAN AREA. EUROPEAN EXAMPLES AND THE RELEVANCE FOR HUNGARY}

\section{IVÁN TOSICS}

The territorial cooperation between the cities and their surrounding areas is of key importance for the competitiveness and sustainability of European development. The new, $21 \mathrm{st}$ century period of city-region cooperation will differ from the earlier versions, giving more emphasys to flexible, governance- and network-type structures, instead of fixed administrative organizations. City-regions have to address double-task: to solve the internal conflicts of the narrow, functional urban area and to exploit the opportunities of the broader, economic cooperation area. The first might need top-down regulatory mechanisms, while the latter might best function in bottom-up partnership. In the Budapest metropolitan area territorial cooperation is non-existent, neither in the narrow FUA nor in the broader economic zone. In the lack of cooperation, regulations and joint development plans based on mutual trust, the Budapest metropolitan area will not be able to solve the internal problems and will be unable to exploit its advantageous European development potentials. 